\title{
Childhood and Citizenship: The viewpoint of the 21st Century
}

\author{
Infância e Cidadania: O ponto de vista do século XXI \\ Infancia y Ciudadanía: El punto de vista del siglo XXI
}

Tom Cockburn*

\section{Abstract}

The latter part of the Twentieth Century saw an increasing recognition of children's claims to citizenship. Significant inroads were made towards children's rights, placed onto the global agenda by the United Nations Convention of the Rights of the Child (UNCRC) in 1989. The academic field in childhood studies responded to this social movement (Cockburn, 2013; Warming, 2011) by problematising conventional models of citizenship into one that would be fit for purpose to apply to children. This article will outline the key features of childhood studies' approach to children's citizenship in the twentieth century. It will then provide a short commentary on the developments this century. Finally, it will identify the themes that are likely to be pertinent now and the near future.

Keywords: Childhood. Citizenship. Twentieth Century.

\section{Resumo}

A última parte do século XX viu um reconhecimento crescente das reivindicações de cidadania das crianças. Incursões significativas foram feitas em relação aos direitos das crianças, colocadas na agenda global pela Convenção das Nações Unidas para os Direitos da Criança (UNCRC) em 1989. O campo acadêmico nos estudos da infância respondeu a esse movimento social (COCKBURN, 2013; WARMING, 2011), problematizando modelos convencionais de cidadania em um modelo que seria adequado ao propósito de aplicar às crianças. Este artigo descreverá os principais aspectos da abordagem dos estudos da infância à cidadania infantil no século XX. Em seguida, fornecerá um breve comentário sobre os desenvolvimentos deste século. Por fim, identificará os temas que devem ser pertinentes agora e no futuro próximo.

Palavras-chave: Infância. Cidadania. Século XXI.

\section{Resumen}

Recebido em 06/01/2020 - Aprovado em 25/03/2020

http://dx.doi.org/10.5335/rep.v27i2.11423

Doutor em Sociologia e diretor do Departamento de Ciências Sociais na Edge Hill University, Inglaterra. Preside a Rede de Pesquisa da Associação Europeia de Sociologia da Criança e da Infância. Participa de projetos europeus de pesquisa, sendo uma referência nos estudos europeus sobre a cidadania infantil e outros temas relacionados à infância e à juventude, Inglaterra. Orcid: https://orcid.org/0000-0002-4705-0633. E-mail: tom.Cockburn@edgehill.ac.uk 


\begin{abstract}
En la última parte del siglo XX se percibió un creciente reconocimiento de las reivindicaciones de la ciudadanía de los niños. Incursiones significativas fueron hechas en relación a los derechos de los niños, puestas en la agenda global por la Convención de las Naciones Unidas para los Derechos del Niño (UNCRC) en 1989. El campo académico en los estudios de la infancia respondió a ese movimiento social (COCKBUM, 2013; WARMING, 2011), problematizando modelos convencionales de ciudadana en un modelo que sería adecuad a el propósito de aplicar a los niños. Este articulo describirá los principales aspectos del abordaje de los estudios de la infancia a la ciudadanía infantil en el siglo XX. Después, hará un breve comentario sobre los desarrollos de este siglo. Por fin, identificará los temas que debe ser pertinentes ahora y en el futuro próximo.
\end{abstract}

Palabras clave: Infancia. Ciudadanía. Siglo XXI.

\title{
Children's Citizenship
}

Much of the literature in the Twentieth Century centred on what has been termed the 'Three Ps' in children's rights: protection, provision and participation (Freeman, 2007). But before discussing these further; it is worth commenting on natural rights. Natural rights are those basic rights that human beings have by virtue of their existence (recently this has been applied to all living beings). Discussion of these rights has a very long history and associated with the development of Christianity and the idea of a soul, however, it is English philosopher John Locke who developed the idea of natural rights into political theory. Locke declared that all people have the natural, inalienable right to "life, liberty and property" (Locke, 1986, first published1694). Thus, all humans should have their personhood recognised in law and with government. However, Locke certainly ruled out children from these natural laws as children possess a "weakness and imperfection of their non-age" (LOCKE, 1986, 148). Thus, children were to be locked out of political theories that formed the backbone of political thought until the Twentieth Century.

A lot happened over the 200 years or so since Locke was writing: the industrial revolution, the abolition of slavery, universal adult and women's suffrage were events that began to enlarge the claims of citizenship from the rather limited and privileged male property owners. By the Twentieth Century the political concerns around children centred around their protection, provision and participation. Starting with protection: children had long had the common law right to life. The industrialised countries of the Nineteenth Century developed this further with a process of protections of children. Beginning with state intervention into children working in mines and factories, then protection from abuse and neglect. By ratification of the UNCRC in 1989 the protections of children were firmly established (protections from exploitation, inhumane treatment, participation 
in wars, amongst others), and a case made for their special status. However, it was this special status, centred around children's perceived vulnerabilities that arguably excluded them from equality with adults.

The second element of children's citizenship: their right to provision had also developed by 1989. By the Twentieth Century children were entitled to the "social rights" (Marshall, 1992) of an education and a basic income to their parents. Under the UNCRC entitlements for children from governments are required to meet their basic needs and help all children reach their full potential. Thus, children are entitled to health treatment, education, leisure, play, culture, social security and an adequate standard of living.

The final element: the right to participation, of all the rights generated the most attention from academics and practitioners (COCKBURN, 2013). This is arguably because it is very hard to get agreement on what participation is and the degree to which 'full participation' is possible or indeed appropriate. Childhood studies, in particular, placed a lot of attention on the processes of participation. Illustrative here is Roger Hart's (1992) concept of a 'ladder of participation' that ranges from 'manipulation' through to “child initiated, shared decisions with adults" (p. 8).

There are of course other important concepts of citizenship than rights. Principally, the counter to rights-receiving individuals are the responsibilities of citizens. Children of course do have responsibilities: a bare minimum is a child's responsibility to their own well-being, care and education; to the tangible responsibilities that children have in the real world; often caring for adults or other children; having responsibilities to earn a paid income, amongst others. Childhood studies correctly addresses the fact that children's responsibilities are rarely given full recognition, as they are performed by children who are subject to processes of misrecognition and whose actions and voice are rendered invisible and denigrated by virtue of the fact that they are performed by children (THOMAS, 2012).

Another important element of citizenship is the notion of belonging. This is becoming more acute in the increasingly globalised world of migration and movement. Tensions within individual children over issues of identity become an increasing focus: be they newly arrived migrants across and within borders, generational mobilities, or sexual identities. All these shape how individual children see themselves, see others, or are seen by others.

By the turn of the Twenty First Century childhood scholars, were grappling with these issues and applied different analytic frames, often associated with 
other social groups asserting their citizenship rights, such as working class people, women, disabled people, minority or indigenous cultures, languages or ethnicities. Thus, childhood studies researchers were interested in citizenship ideas that reflected an inclusive element to citizenship (Lister, 2008). Warming and Fahnøe (2017) developed the concept of 'lived citizenship' (p. 4) drawing on ideas of radical democracy and inclusion associated with the ideas of Moosa-Mitha (2005) that emphasised processes of positioning and identity formation, rather than citizenship as a state or status. Thus, the lived citizenship position was interested in "who is and feels included, excluded or not least on the edges, emerges from the multiple everyday interactions between people in which they perform, learn and experience citizenship as a self-other relationship" (WARMING; FAHNØE, 2017, 5).

\section{Children's Citizenship Today}

Childhood studies is currently adapting to other global processes. The first, and in no particular order, is the climate crisis. This for children is a vital issue and recently children and young people have taken up the role of leadership: Greta Thunberg and tens of thousands of child activists like her around the globe staged the Global Climate Strike, the latest held on $21^{\text {st }}$ September 2019. The second process involves the increasing geographical mobility of people across the world today. Be that migration from the countryside to cities (Unicef, 2012), migration within nation states and migration across countries (Falkingham, 2001) and at times across continents (KAGITCIBASI, 1996, de GLIND; KOU, 2013). There is an acknowledged sense of urgency on how migration effects children's wellbeing from 15 hours per week commute to school in Seoul to their risks in exploitation and trafficking (WHO, 2018). Finally, there is an increasing recognition that conventions, such as the UNCRC, require focus and attention by academics from the Global South (HANSON, 2018). Amongst this attention has been a perceived danger of imposing a minority world idea of 'appropriate' childhood on others; such as a description of 'globalised childhoods' based on models of childhood premised on minority world understanding of childhood identified and critiqued by Kaufman and Rizzini (2002).

Childhood studies, therefore, in order to analyse the processes of lived citizenship has focused on the concept of children's agencies within specific spaces. The latter part of the Twentieth Century childhood studies researchers have paid attention to the 'everyday' spaces where children live and exercise their agencies. 
These everyday spaces include their relationships with families, their friends, their streets, amongst their peer groups in schools and so on. Researchers wished to 'reclaim' children's agencies and counter the passive image of children in the then existing sociological, psychological, educational and developmental discourses. The seminal Prout and James (1990) book Constructing and Reconstructing Childhood successfully argued for the position of taking seriously the idea of children as effective social actors. The focus of the plethora of studies that followed looking at children's participation and agency identified two main conclusions. The first identified that children's agency in their social connections and participation was seen in relatively consensual and structural terms: often these were understood by placing children within generational orders (ALANEN, 2009) vis-à-vis their relationships with adults and within the adult frameworks of education, patriarchy, class and governance more broadly. Secondly, researchers noted that children enact their agency in both positive and negative ways. Yes, when looking at children in their lived social relations they made constructive, telling, observant and important contributions (PERCY-SMITH, 2010), as Baraldi (2012) notes adult structures have an element of unpredictability when subject to children's actions. However, these were made within adult structures where adults held the power. Malcolm Hill et al (2004) noted that children's institutional participation in adult structures formulated a rather 'thin' form of agency; as participation was a way of co-opting children into those very adult structures, leaving very little room for directing social change.

This led to a large body of theoretical literature on creating a more nuanced understanding of children's agency. Madeleine Leonard (2015), for instance, looked at how generational positioning within structures allows children to construct, coconstruct and reconstruct their lives in a process of 'generagency' (p. 4). In this sense children's agency unfolds in an interdependent and complex manner. David Oswell and more recently Spyros Spyrou further problematise children's agency within a whole host of complex structures, not just between adults and children but also between things and spaces. Thus, children's agency becomes enacted or constrained within specific geographical contexts, within discursive regimes and mediated by texts and technologies.

So, given the complexities of children's agency and their lived lives, where does this leave childhood studies? As Claudio Baraldi and I argued recently (Baraldi and Cockburn, 2018) this leads to six important elements to current research that are firmly interlinked. Firstly, it is necessary to accept theoretical pluralism to 
match the heterogeneous nature of children's lives across the globe and within communities. Secondly, concepts, such as citizenship, need to be applied to the lived citizenships as experienced by children in specific contexts: how do children interact with the welfare state; what are their social identities of belonging; how do children experience education systems? Thirdly, how do these lived experiences intersect with intersectionalities of class, gender, ethnicity, (dis)abilities and so on? Fourthly, it is necessary to make visible those lived childhoods that are not visible in intergenerational relations. Children under seven years of age or those children who have yet gained sufficient linguistic skills to express their wishes or concerns are largely absent from citizenship discussions. Fifthly, it is still necessary to continue to subvert existing social and cultural presuppositions of childhood by elaborating children's own lived conditions, experiences and explanations. Finally, this must be achieved by seriously acknowledging the 'glocal' dimensions in children's lives.

Taking the last point as an exemplar of the challenges to understanding children's citizenship, it is important to acknowledge the diverse experiences, social structures and lived lives of children both as a plurality across the world (chiefly but not exclusively between the minority and majority worlds) but also within specific nation states. As noted above childhood studies is increasingly recognising the colonisation of childhood from the minority world and scholars in Europe, North America and Australasia identify, have problematised and theorised the condition of children in the Global South. The work of Sharon Stephens (1995) onwards have studied the power relations that children in the majority world inhabit; playing particular attention to hegemonic structures that international development demands. Such work has, correctly, mapped processes of children's poverty, exclusion, injustices and marginalisation. It has also brought to the attention of academics and policy makers in the minority world such processes and the role the international development movement plays in sustaining those processes. For instance, Pells notesthe ways in which the minority world imposition of 'Western' child rearing practices has located majority world children as lacking and in deficit. They also suffer from process of misrecognition, emphasising vulnerability, pathologisation and otherness, that is hard for those children and their carers who strive through exploitational economic circumstances to make the most of their lives (PELLS, 2012).

More excitingly, there is a growing body of work from academics from the majority world itself. Such work provides more nuanced understanding of children 
in their local situations and how these fields are interconnected with global political, economic and cultural structures (ABEBE, 2013). Abebe (2013) shows how economic restructuring and neoliberal economic processes weaken a nation state's ability to support children. In Ethiopia Abebe maintains that the muchneeded foreign investment served to displace communities from their means of subsistence in more collectivised societies. There becomes a disjuncture between the needs and rights, based on a relationship with the state; and those reciprocal belongings based on child/family and intergenerational relationships in their communities. Children's agency within majority world communities tends to be obvious: children produce, reproduce and contribute. However, what is missing is a focus on the ways economic and political oppression intersects with children's lives, according to age, ethnicity, gender, and so on. It is only when such processes are understood that strivings for more distributive justice can be deployed.

It is therefore imperative for childhood studies to develop, or at least be mindful of, a comparative analysis of the workings of the state and transnational capital on the lives of all children, marginalised or privileged, in both the majority and minority worlds. Relatedly, children's lives are closely interrelated with processes of international trade that effects labour and education markets. Trade and labour markets have also increased processes of migration and mobility, both within and between nation states and even across continents. Migration patterns have thrown up further phenomena for citizenship analysis where families have become more 'intercultural', or, the ways in which children are exposed to diverse cultures, where their cultures interact and change in their interactions with other cultures. This impacts on children in terms of their identities as they may be children of parents through marriage or partnerships across cultures. Or they may, as children, cross from one culture to another, most often through migration. This has led to, at times, a ‘superdiversity' where children may move multiple times across different cultures, each experience leading to familiarity with other cultures with all the potential opportunities and challenges this may involve. Thus, there are situations where migrants and ethnic minority groups constitute a high percentage of a population; their national origins are highly diverse and there is a mix of migration statuses and associated rights (VERTOVEC, 2007).

The other process affecting citizenship identities and related to the 'intercultural' experiences of children is around media communications. Firstly, with the rise of social media, more traditional processes of media have been subverted. On one level this is a good thing, in that traditional media tended to be 
owned by vested, and powerful interests; the rise of social media has allowed the voices of those traditionally marginalised, such as children, to have a platform to express their views and share information, discuss topics of mutual interest, and work towards common goals. People, goods, services, and information from many diverse locations flow in and out of places daily, creating a 'progressive sense of place' (MASSEY, 2015, 19), where the character of a place is shaped as much by processes from outside intersecting with it as those acting within it. This creates tangible opportunities for children to express their citizenship identities, however, as David Harvey (2001) has cautioned, technological developments are being driven by the need to reduce the turnover time of capital, and produced in order to facilitate capitalism's reach and accumulate capital. Thus, locking all children, wherever they are, into process of alienation, exploitation and control.

So, what does all this mean for theorising children's citizenship in this complex, interconnected and fluid world? One alluring idea is that of cosmopolitanism. To be 'cosmopolitan' is to be 'well-travelled' and genuinely curious about the world. With roots stretching beyond Immanuel Kant in the eighteenth century and arguably to the European classical period. With processes of 'glocalisation' outlined above, the hybrid nature of many people's identities, the superdiverisities of much of the localities where people live, ideas of cosmopolitanism have proved attractive. Theorists have turned to ideas of cosmopolitanism to create environments that are less essentialised and demonising in order to bond class, ethnic and other divisions and create greater social solidarity and respect (Amin, 2006).

A final note on the current state of research into children's citizenship is the influence from the 'post-humanist' turn in childhood studies associated with the work of Nick Lee (2001) and later, Spyros Spyrou (2011, 2018). This important research provides further nuance to capturing the complexity of children's agency by critiquing the 'humanist' and 'rationalist' assumptions in research with children. Spyrou (2011) captures the point well in his reflections on his research into Greek-Cypriot children's understanding of national identity. Spyrou begins by questioning current childhood studies research that claims to capture a true and authentic children's 'voice'; beginning with pragmatic observations about the time constraints that are part of a modern researcher's contractual life to identifying three key observations. The first of these is that researchers do not sufficiently critically reflect upon their positions of power in their representations of children's voices. Secondly, researchers do not adequately make clear their own assumptions about children, the language we deploy as researchers and theorists, the ideological 
and institutional contexts in which research operate. These multiple factors constrain and shape our constructions of children in our research, in what children say and the identities that they express. Finally, Spyrou cautions researchers who seek to identify a unitary subject speaking the truth; rather, it is necessary to acknowledge the 'polyvocality' of children's voices where children's voices shift and change according to the discursive possibilities that range and vary according to context. He describes this point well when reflecting upon his own work with Greek-Cypriot children constructing their identities, They:

resorted to a more official, nationalistic voice when expressing their identities at school. The structured and highly controlled space of the school encouraged children to provide the 'correct' answer while the more child-controlled neighbourhood playground provided them with significantly more leeway to draw upon alternative discourses which in some cases undermined or contradicted the ones they drew upon at school (SPYROU, 2011, p. 155).

At the first level, the Greek-Cypriot children understood 'Turks' as invaders, evil, and so on. However, after time and with more understanding the notion of 'Turks' and the negative attributes was associated with some Turks, such as the government and army, but not all Turks. Indeed, children in more informal, relaxed contexts referred to a more positive viewpoint of Turkish-Cypriots in a more hyphenated and nuanced manner. The important point made is that children's citizenship identities and their viewpoint of others, even traditional `enemies', can be framed differently in different discursive contexts by the same children. The importance for childhood studies scholars is the necessity to lay bare the varying practices, discourses and narratives of citizenship.

\section{Children's Citizenship: Future Directions}

In terms of thinking through children's citizenship we have the benefit of recent theoretical contributions. Following the point made in the last section is the significance of the 'post-human turn' and the prominence to taking 'relationality' seriously. Of course, this is not new; this author's early writings on citizenship emphasised the requirement to take interdependence seriously for both adults and children (COCKBURN, 1998). Building on the requirement of childhood studies to go, as Peter Kraftl maintains, 'beyond children's agency' $(2013,14)$ it is necessary to take a reflexive approach to our own standpoints and our representations of children. Children's lives involve close family members, are located in local communities, in local education systems, local economies, local (social) media 
that are at the same time increasingly shaped by global forces. Each of these elements profoundly shapes children's lives, those of their parents and carers, the professionals that work with children and the communities in which children live. In this respect the natural rights theories of John Locke and the individual, independent, rational person his theory assumes is inadequate - for adults as well as children. Relationality is built in to the human experience.

The complexity of our theorising of citizenship identities becomes further intricate when we add the importance of 'differences' and other 'intersectionalities' into our theorising. Such intersections include gender, as gender identities still profoundly shape the experiences and life chances of boys as well as girls across the globe. This calls for a close interest in recent feminist theorising around citizenship, some feminist theorising specifically focusses on the gendered citizenship identities of children. This involves a review of our sociological ethics and theory (SEVENHUIJSEN, 1998; Cockburn, 2005) and an engagement with feminism's 'post-human turn' (BRAIDOTTI, 2006) as well as other intersections based on ethnicity and colonialism (SAADA, 2012).

Added to the importance of interdependence and intersectionalities to children's citizenship identities are the processes of 'social recognition'; a full analysis of recognition theory and its application to children has been undertaken by Nigel Thomas (2012). Children, he argues, are morally responsible persons, are therefore rights-bearers and entitled to respect. In addition, children are embodied people with talents and capabilities, who contribute in a variety of ways to society and culture, and so are deserving of esteem. Thomas convincingly argues that an analysis of children's intersubjective claims to love, rights and solidarity are crucial to understanding the dialogue between children's identities, what children think is right, and their ability to change things (THOMAS; STOECKLIN, 2018). It is worth now returning to the beginning of this text and note Freeman's 'three Ps' of participation, protection and provision. Processes of recognition are key to understanding children's participation and protection but also to provision. Nancy Fraser (1997) correctly focuses on a radical redistribution of social resources in favour of marginalised or misrecognised groups of people. However, 'redistribution' usually involves top-down interventions by the state, either from the political left or the right. Neither of these approaches involves what might be called 'bottom up' interventions. This must involve a politics of redistribution that on the one hand speaks to individual rights and belonging but also to more collectivist claims through the intersections of class, ethnicity and gender alluded to above. 
It is necessary therefore to have recognition of children that avoids a 'top-down' clumsy manner before redistribution can happen; at the same time redistribution is necessary so that groups can find a way of greater community mobilisation.

Finally, it is essential to identify the greatest challenge to children's expressions of citizenship and that is by acknowledging the form of control over children. This will be difficult to develop fully in the context of this text. However, control over children happens on a number of levels; each profoundly shaping and constraining the social recognition of children. These processes link to the discussion above about the limits to children's agency. Control of children occurs at the basic familial level where children's citizenship is shaped by family mechanisms; notably there is a persistence to processes of patriarchal control, even in economically developed countries with long established equal opportunities legislation. Children's location within households have their views shaped by the familial cultures in which they live, these are dominated by parents or other senior (adult) family members. In terms of economic control these are sometimes controlled through families directly, but economic wellbeing is assigned as an accident of birth where some children are dealt the cards more fairly than others. Children's social recognition is still constrained discursively; Nicolas Rose's (1999) Foucauldian analysis established the discursive construction of reality of societies and the crucial means by which social control is directed through children in the education and health systems by defining as 'normal' an unquestioning striving for educational qualifications, 'good' bodies and 'ill' bodies. Children remain discursively constructed as 'vulnerable', 'innocent'. 'blank slates that education is needed to shape', 'damaged' bodies to which power/knowledge deploys its medical and psychological regimes upon, and so on. These discourses continue to shape and damage children's claims to political citizenship, across all parts of the globe and still remains a major project of childhood studies to analyse, deconstruct and challenge such constructions.

\section{Childhood and Citizenship: Changing the Narrative?}

Challenging discourses that marginalise children, producing work that supports children's social recognition and redistribution, affirming intersectional solidarities, as well as locating these amidst children's processes of interdependence is an important agenda for childhood studies researchers and their supporters. However, what discourses for citizenship are available for children? As mentioned above, ideas of Cosmopolitanism would fit well, especially in cities, as exemplified 
by Delanty's (2006) ‘critical cosmopolitanism' and in understanding day-to-day forms of social solidarity as described through Paul Gilroy's (2004) analysis of the 'conviviality' of social groups in superdiverse communities. As Gilroy (2004) notes in the optimistic side of his book, race and ethnicity become less important for young people in today's British cities. However, this does not mean an end to racism and division in our societies, panics about asylum seekers; hostility to new eastern European immigrants; fear of "black" gun crime; fear of infiltration by foreign or Muslim terrorists, suggest in many respects a backward step in race relations.

There are, of course, important localised projects that children become engaged in to challenge for social justice. Notable examples are led by those children and young people in the developing world. The 'Penguin Revolution' in Chile in 2006 were a series of protests by high school students between April and June 2006, culminating in strikes and marches on 30 May being the largest student demonstration the country had seen. The protestors' demands ranged from the delivery of free travel passes on buses to a high-quality education of all. Some of the demands were accepted by Michelle Bachelet's government and served to quell some of the demands of the students. This did not end the discontent with other surges in protests in 2008 and between 2011-13, not all the demands have been met and Chile continues to have a large portion of schools under the private sector. However, some demands were accepted by the government and children remain a vociferous opposition to national state politics.

In Brazil the Rozelinhos consisted of crowds of young people in 2013 and 2014, including many people of colour, coming together to protest at being excluded from shopping malls and exclusive sites of consumerism and other public spaces. The protests were organised on social media and included other marginalised groups of young people, such as those who are homeless. While the protests had very little of their objectives realised they had certainly registered alarm amongst social elites. The focus of protestors on commercial places demonstrates the intertwining of citizenship with consumption and citizenship; a new claim to citizenship and protest against exclusion that is likely to be shared with all young people across the globe. While nation states guarantee the formal equality and inclusion of citizens, however, the substantive distribution of rights is still done along the lines of privilege and unequal power relations.

This arguably for this author hits the crux of the problem for children's citizenship in today's neo-liberal world. John O'Neill (1994) in his classic book 
The Missing Child in Liberal Theory provides a critique of market societies, then and now, being advocated in today's market capitalism. O'Neill observed an encouragement of minimal civic obligations and a maximum participation in market capitalism and consumption. O'Neill centres the importance of the context of children's lives: children themselves; their families; and communities, but places this in the wider context of political economy and market capitalism. The latter providing children with very little civic attachment and will produce a society that is hostile to social solidarity and justice. The solution, for O'Neill is to provide a re-affirmation of the civic foundations of the state. While, a re-affirmation of a civil state with a generational contract is an admiral ambition, how we get there is open to debate. The experiences of the Pinguino 'Revolution' and the Rozelinhos testify divisions and class antagonism prevail if the aims of the movements base themselves on narrow narratives of 'consumption citizenship'. A deeper series of narratives are required. A variety of radical narratives do exist, the most exciting is the global phenomenon of children opposed to the climate emergency, led by Greta Thunberg and other children and young people. However, the objectives will not be achieved through narratives of market and consumer capitalism but through a deeper societal retrenchment willing to adopt redistributionist policies and this is only coming from the political left.

Across the world there is a resurgence of 'community politics': from the recent Brexit vote in the UK; nationalist governments in Hungary and Poland; the reelection of Narendra Modi in India; Recep Tayyip Erdo $\square$ an in Turkey; Rodrigo Duterte in the Philippines; and the election of Jair Bolsonaro in Brazil. However, this 'community' politics is populist and dominated by the divisive and toxic discourses of a resurgent far right. The discourses deployed are simplistic and feed into the discomfort and scepticism of politics in general, perhaps as identified and feared by O'Neill. The discourses deployed by populists engage with fundamental issues such as education, housing, transport and health with the blame for inadequate policies, not neo-liberal policies which they share, but with a myth of an 'urban elite' and an influx of immigrants that have placed residents at the bottom of the pile. This must be opposed, and new narratives deployed in their place. These must include redistribution of wealth, a central role for local, national and international state polities, and an inclusive rhetoric based on shared humanity. This can only be delivered from the political left. The question remains whether those from the political left are able to shift from the limited and sometimes poor practices of socialist states in the twentieth century to develop a political and economic 
vision able to engage with processes of social interdependence, fluid identities, misrecognition and generational structures that pattern the citizenship of children today.

\section{Bibliografy}

Abebe, Tatek (2013) Interdependent rights and agency: The Role of children in collective livelihood strategies in rural Ethiopia in Hanson, K. and Nieuwenhuys, O. (eds)

Reconceptualizing Children's Rights in International Development, Cambridge: Cambridge University Press, pp. 71-92.

Alanen, Leena (2009) 'Generational Order' in J. Qvortrup, G. Valentine, W. Corsaro and M. Honig (ed) The Palgrave Handbook of Childhood Studies, Basingstoke: Palgrave 159-174.

Amin, Ash (2006) 'The Good City', Urban Studies, 43(6) 1009 - 1023.

Baraldi, Claudio (2012) Participation, Facilitation and Mediation in Educational Interactions,' in C. Baraldi and V. Iervese (eds) Participation, Facilitation and Mediation, London: Routledge 66-86.

Baraldi, Claudio and Cockburn, Tom (2018) Theorising Childhood: Citizenship, Rights and Participation, Basingstoke: Palgrave Macmillan.

Braidotti, Rossi (2006) Posthuman, All Too Human: Towards a New Process Ontology, Theory, Culture and Society, 23(7) 197-208

Cockburn, Tom (1998) 'Children and Citizenship in Britain: A case for a socially interdependent model of citizenship' Childhood: A Global Journal of Child Research, Vol.5(1) 0907-5682, pp. 99-117.

Cockburn, Tom (2005) 'Children and the Feminist Ethic of Care', Childhood: A Global Journal of Child Research, Vol. 12(1) pp. 71-89.

Cockburn, Tom (2013) Rethinking Children's Citizenship, Basingstoke: Macmillan

Delanty, Gerard (2006) The cosmopolitan imagination: critical cosmopolitanism and social theory, British Journal of Sociology, 57(1) $25-47$.

Falkingham, J. 2001. 'From Security to Uncertainty: the impact of economic change on child welfare in Central Asia' pp. 227-254 in K. Vleminckx and T.M. Smeeding (eds.) Child Wellbeing in Modern Nations. Bristol: The Policy Press.

Fraser, Nancy (1997). Justice interruptus: critical reflections on the "postsocialist" condition. London: Routledge.

Freeman, M. (2007). Article 3. The best interests of the child. In A. Alen et al. (eds), A Commentary on the United Nations Convention on the Rights of the Child. Leiden, the Netherlands: Martinus Nijhoff.

Gilroy, Paul. (2004) After Empire: Melancholia or Convivial Culture?, London: Routledge. 
Hanson, Karl (2018) 'Global/local research on children and childhood in a 'global society', Childhood 25(3) 272-296.

Hart, Roger (1992) Children's Participation: From tokenism to citizenship, Florence: UNICEF. Harvey, David, Spaces of Capital (2001) New York: Routledge

Hill, M., Davis, J., Prout, A. \& Tisdall, K. (2004) 'Moving the Participation Agenda Forward', Children and Society, 18(2) 77-96.

Kagitcibasi, C. 1996. Family and Human Development across Cultures: A View from the Other Side. Lawrence Erlbaum, Mahwah.

Kaufmann, N and Rizzini, I. (2002) Globalization and Children, London: Plenum publishers

Kraftl, Peter. (2013) Beyond 'voice', beyond 'agency', beyond 'politics'? Hybrid childhoods and some critical reflections on children's emotional geographies. Emotion, Space and Society. 9: 13-23.

Lee, Nick (2001) Childhood and Society: Growing up in an age of uncertainty, Buckingham: Open University Press.

Leonard, Madeleine (2015) The Sociology of Children, Childhood and Generation, London: Sage.

Lister, Ruth (2008) 'Unpacking Children's Citizenship' in Antonella Invernizzi and Jane Williams (eds) Children and Citizenship, London: Sage 9 - 19.

Locke, John (1986) Two Treatises of Government, London: Everyman.

Marshall, Thomas (1992) Citizenship and Social Class, London: Pluto.

Massey, D. (2005), For Space. London: Sage.

Moosa-Mitha, Mehmoona (2005) `A Difference-centred Alternative to Theorization of Children's Citizenship', Citizenship Studies 9(4) 369-388.

O’Neill, John (1994) The Missing Child in Liberal Theory, Tornoto: University of Toronto Press.

Pells, Kirrily (2012) 'Rights are everything we don't have': Clashing conceptions of vulnerability and agency in the daily lives of Rwandan children and youth. Children's Geographies 10(4) 427-440.

Percy-Smith, Barry (2010) 'Councils, Consultation and Community: Rethinking the spaces for children's participation', Children's Geographies 8(2) 107-122.

Prout, Alan and James, Alison (1990) Constructing and Reconstructing Childhood, London: Falmer.

Rose, Nikolas (1999) Governing the Soul: The shaping of the private self, London: Free Association Books.

Saada, Emmanuelle (2012) Empire's Children: Race, filiation and citizenship in the French colonies, Chicago: Chicago University Press.

Sevenhuijsen, Selma (1998) Citizenship and the Ethics of Care: Feminist considerations on justice, morality and politics, London: Routledge. 
Spyrou, Spyros, (2011) 'The Limits of Children's Voices: From authenticity to critical, reflexive representation', Childhood, 18(2) $151-165$.

Spyrou, Spyros (2018) Disclosing Childhoods: research and knowledge production for a critical childhood studies, Basingstoke: Palgrave Macmillan

Stephens, Sharon (1995) Children and the Politics of Culture, Princeton, NJ: Princeton University Press.

Thomas, Nigel. (2012). Love, rights and solidarity: Studying children's participation using Honneth's theory of recognition. Childhood, 19(4), 453-466.

Thomas, Nigel and Stoecklin, Daniel (2018) 'Recognition and Capability: A new way to understand how children can achieve their rights' in Baraldi, Claudio and Cockburn, Tom (Eds) Theorising Childhood: Citizenship, Rights and Participation, Basingstoke: Palgrave Macmillan. 73 - 94 .

Unicef (2012) Children in an Urban World, New York: UNICEF.

Van de Glind, Hans; Anne Kou (2013). Migrant Children in Child Labour, A vulnerable group in need of attention, International Organisation of Migration, Children on the Move. Geneva: ILO-IPEC, pp. 27-43, p. 30.

Vertovec, S. (2007), 'Superdiversity and its implications', Ethnic and Racial Studies 30: 1024-54.

Warming, Hannah (2011) ‘Children's Participation and Citizenship in a Global Age', Social Work and Society, 9(1): 119-134.

Warming, Hannah and Fahnøe, Kristian (2017) Lived Citizenship on the Edge of Society: Rights, Belonging, Intimate Life and Spatiality, London: Palgrave Macmillan.

WHO (2018) Health of Refugee and Migrant Children, Copenhagen: WHO. 